\title{
Subjectivities of Russian Traders at the Border with China
}

\author{
CAROLINE HUMPHREY
}

\begin{abstract}
This paper draws attention to a relatively understudied aspect of cross-border trade: the relation between the subjectivities of traders and the geo-political situation they find themselves in. Among Russian traders at the border with China, discourses on comparative civilisation, memories of mid-twentieth century Soviet dominance and ambivalent appreciation of China's present riches are integral to everyday practices. It is argued that a theoretical concept of melancholia is helpful to understand the traders' self-reflective and diverse reactions. At this highly securitised border, in the absence of deep social relations with Chinese partners, the goods purchased, consumed and traded appear as vivid alternative foci for emotions. The article suggests that an anthropological approach to qualia (experiential feelings aroused by material objects) provide a useful heuristic for discussion in this situation.
\end{abstract}

Keywords: shuttle-trade; materiality; qualia; imagination; self-reflection

This article is concerned with the understanding of the practices, reflexive attitudes and feelings of people who conduct small trade across the stark northeastern border between Russia and China, one that is not only political but also economic, social, linguistic and cultural. Much of the literature on borders has focused on hybridity, flows and cross-border linkages. Only more recently has attention been paid to the ways in which the demarcations that nevertheless exist are imagined and can be analysed. Franck Billé (2017) has made a notable contribution in this regard, especially in a recent paper that employs the analogy of border-as-skin. He posits the elasticity of skin as a topological and sensory metaphor for the way in which people experience the touching of two imagined geo-bodies (Billé 2017: 8). This article does not seek to theorise a metaphor for borders in

This article can be accessed at https:/ / doi.org/10.22439/cjas.v39i1.6177. 
general or the Sino-Russian border in particular, but rather to explore a more social anthropological question: the complex subjectivities of Russian citizens, who cannot ignore the existence of the securitised border and the difficulty in crossing it, but constantly have to work with such obstacles, since it is through extracting benefit from breaching the border that they make a living. The article has two aims: first, to suggest a widening of the parameters of research on cross-border traders by taking into account the prevailing ideological and historical suppositions about developmental difference between Russia and China; and following on from this, to suggest how the present evident contradiction of these presumptions gives rise to a complex subjectivity that is apparent above all in the sensations, affect, imaginative properties and cynicism attached to the material goods traded.

In both Russia and China, histories, analyses and popular media represent their common border as a 'civilisational' break (Bassin, Glebov and Laruelle 2015; Humphrey 2012). This short article will, however, primarily concern the Russian side. The Russian word tsivilizatsiya has different implications from the English equivalent, since the idea is developmental and hence evaluative. It designates the 'level' (uroven'), less or more evolved, of social, material and spiritual development of a given socio-economic formation. Many early twentieth century theories that found their way into public consciousness, from the Eurasianist to the Marxist, proposed the Russian social order to be more advanced than the Chinese, and therefore justified the promotion of a 'civilising mission' in the East (Bassin, Glebov and Laruelle 2015: 1). Soviet domination of international socialism only reinforced this understanding. Today, such a view is widely queried in Russia, and yet it is bolstered by government campaigns to promote patriotism that have intensified since 2014 . Seeking to unify society around the themes of shared statehood, sacrifice and achievement (Goode 2018: 258), the Federal Programme for Patriotic Education has a broad cultural, social, religious, etc., scope and can be seen as an attempt to elevate the meaning of Russian tsivilizatsiya in the contemporary world. In this context, patriotism has become an inescapable part of public life, both enthusiastically displayed and privately contested (Daucé et al. 2015; Goode 2018). This 'civilisational', world-historical way of thinking faces the increased loudness of the discourse of 'civilisation' (wenming) in China. The latter, by contrast, is not conceptualised as an evolutionary 
achievement but as an age-old characteristic of the innately superior Chinese culture. One of the suggestions of this article is that the confrontation of these incompatible ideas is central to understanding the subjectivities of Russian citizens at the border - including, unlikely as it may seem, among hardworking traders. It should be noted that just as the concept of tsivilizatsiya applies to the multi-national conglomerate of the Russian Federation, the term 'Russian' as used in this paper applies to all citizens whatever their ethnicity unless stated otherwise.

By 'subjectivity' I refer to the feelings and perspectives that inform and influence people's judgements about the actuality that surrounds them, and I am more interested in subjectivities that are socially embedded and seem to be shared than idiosyncratic or purely personal cases. In the context of discussions of 'everyday bordering' (Donnan et al. 2017; Yuval-Davis, Wemyss and Cassidy 2017: 1047; Reeves 2013), the self-reflexive views of economic actors - buyers, consumers, sellers, carriers and distributors - is a relatively understudied theme. I argue that subjectivities and moral musings on non-economic matters, such as one's nation's standing, judgement of the current state of society, pride in war-time exploits, attachment to home or foreign landscapes or narratives of gendered fortitude, should not be seen as add-ons to some underlying commercial rationality, but as integral to the ways in which traders understand their activities.

The terrain in which such feelings and imaginings play out is composed of various forms and sites of cross-border interaction that have emerged since the 1990s. They include markets and malls, commonly patronised cafés, mobile phones with switchable sim cards, storage depots, multiple-occupancy rooming houses and bus and ferry journeys, all lubricated by the limited trade jargon (a form of basic Russian) that is used along the border. Yet even traders who travel frequently to China very rarely speak fluent Chinese, and they have almost no social contacts beyond business. They are caught in the trap of not knowing about abrupt changes in regulations - the regular attempts by the authorities on both sides of the border to control the flow of contraband. Therefore, they have to operate with the rather few mediators (agents, translators, legal experts) who know both languages, can find business partners and exercise some control over the fulfilment of orders (Ryzhova 2020: 157). The thinness of social contact is one reason why it is not so much people as, crucially, the 
objects of trade that are so central to the formation of the traders' subjectivities. ${ }^{1}$

This article's focus on materiality is also motivated by the fact that most Russian 'small traders' are also (and even mainly) consumers. The things brought from China are close to them, because they themselves eat, wear and use, as well as sell, them. In one trip, they often combine buying in order to re-sell with buying for themselves and their families, as described further below. This means that the experiential affect produced by a material object for consumption (for example 'a crisp white shirt') is entangled with its imagined value as a trade good. The shirt is qualified and re-valued as soon as it is perceived to be 'Chinese-made' or 'Russian-made'. In the next section, I introduce the theoretical notion of qualia to explain how such qualitative value judgements not only affect prices in local markets, but at the same time are linked to emotional imaginaries about nations and their characteristics.

The desirability of goods is modified by branding, and markedly so in the case of global brands. It has been argued (Ermann 2013) that global branding can have a liberating, prestige-generating effect on consumers in post-socialist countries by creating a super-national sphere of imagination. My ethnography suggests that this indeed can sometimes be so. But I will also argue that in the era of 'fake news' and media savvy youth, branded goods are rarely taken at face value. For the most part, there is nothing truly transcendent about the globalised imagination; instead, amid widespread cynicism, it curls back on itself allowing the national stereotypes to reappear, setting in train painful comparisons and bruised, self-reflexive musings. To analyse this, and to complement the discussion of qualia, I call upon a second theoretical idea, that of melancholia.

\section{Theorising Subjectivities}

In attempting to relate subjectivity to the materiality of economic activity, this article has been influenced by the work of Yael Navaro-Yashin (2009) concerning the ways in which people deal with the 'otherness' created by another harshly delineated border, that in the divided island of Cyprus. Navaro-Yashin's subject matter is fairly different - namely, the emotive energies discharged by the properties and objects left behind after a war by the 'enemy' Greek Cypriot community after they were appropriated by Turkish Cypri- 
ots. However, her analysis of the 'melancholic interiority' (2009: 5) associated with having to live with and use on a daily basis objects 'plundered' from the fleeing other and the unease generated by the use of 'dirty' ('abjected') materials, such as clothing abandoned by the Greeks, provides many insights with regard to the subjectivity of Russians engaging with the Chinese cornucopia. Given that it is overwhelmingly Russians who buy and use Chinese consumer goods and not vice-versa, it is primarily the former who are faced with the jolt, be it great or barely perceptible, of the otherness that saturates the acquired material objects, the unavoidability of intimate engagement with them and the necessity to domesticate and normalise them in their own social order. Navaro-Yashin argues (2009: 6) that for the Turkish Cypriots the uneasy quality of alien objects is 'not an exteriority against which subjectivity and sociality are to be defined (challenging [...] from without) but is rather fundamentally an interiority' that is intrinsic to the subjectivity characteristic of the present political system (see also Billé 2017: 13). The same is true, I suggest, of the disquiet of Russian citizens' inner acknowledgement that they collectively have chosen to be daily purchasers and consumers not of their own but of Chinese goods.

I have adopted Navaro-Yashin's concept of 'melancholic interiority' to explore this situation for reasons that can be explained by comparison with Kathryn Cassidy's (2017) insightful paper about another border of the former Soviet Union, that of Ukraine-Romania. Cassidy's work highlights the involvement of memory and deeply internalised emotion in cross-border small trade. Ukrainian villagers, being citizens of the USSR, had previously been the more prosperous and prestigious. Now, they express shame at their women's present need to engage when trading in sexualised performances pandering to masculinist Romanian officials, especially since the former 'poor neighbours' are now in the economically advantageous situation of EU membership. By contrast, my research has not found shame to be the only or even the primary emotion expressed by Russians facing China. Gender hierarchies are structured differently in Eastern Europe, and sexuality is less associated with guilt/shame (Lacaze 2012). Furthermore, any affect Russian border crossers feel at purchasing and absorbing the materiality of the newly rampant 'other' is complicated. It does not erupt in the form of a single emotion, such as shame, but becomes manifest in diverse ways. Melancholia, if we adopt a Freud-influenced 
meaning, ${ }^{2}$ is grief for a loss that a person is unable fully to comprehend; it is a largely unconscious process taking place and may express itself in ambivalent ways that cannot be simply reduced to sadness but could be compensatory, moralising or aggressive (Clewell 2004). The ambivalence inherent to melancholia in this sense is appropriate, I suggest, in the situation discussed here, where the attitude of people towards the lost Soviet past, and even more so to the current Russian state, is itself ambiguous and conflicted (Cherkaev 2014).

How does such a subjectivity relate to trade practices and the materiality of goods? Trans-national trade is not only a matter of fluctuating prices, duties, trade standards and currency swings, it is also an economy of perceived signs, sensations and moral evaluations. To address such issues, it is necessary to have a way of analysing the experienced quality of goods that is not reduced to monetary price. This is why I adopt the concept of qualia, a philosophical term that can be defined as a quality or property as perceived or felt by a person. Qualia are the phenomenal qualities of experience, such as the taste of an apple - not apples in general, but this apple, now. An ethnography of trade on such a border should not ignore such feelings on the grounds that they concern only individual psychology or are so ephemeral they are impossible to pin down. These experiences have effects and lay down clues, above all seen in what people say in unguarded moments; this points to the nature of subjective apprehensions and judgements, which may be individually voiced but are also communicable and shareable.

So, while qualia are seen in philosophy as unknowable and inaccessible - I cannot know exactly what you are feeling when you seem so red-faced and angry (Luhrmann 2006: 349) - anthropologists have expanded the idea for broader theoretical use. They have argued that qualia are not just individual-private subjective mental experiences but can also be 'socio-cultural events of evaluation' (Chumley and Harkness 2013: 3). Adopting a similar approach, Alaina Lemon (2013: 67) has coined the expression 'social qualia', defining the idea as follows:

[They] are matters neither of unmediated sensation, nor of symbolic construction alone. They merge qualic signs - bread's saltiness, an eye's lustre - with histories and taxonomies, with bodily apprehensions of people, and of geopolitics.

Thisallusion to 'histories and taxonomies' gives us thelink to melancholia, 
for a sensation of loss inevitably involves the past, in whatever form the subject conceives that past to have taken. Later in the article, I attempt to demonstrate this link through ethnographic examples. But first, since borders are inevitably complex terrains, it is necessary to provide some background information.

\section{Asymmetries of Border Trade and Social Caricatures}

To provide context, let me first briefly describe the current economic scene. Chinese central and local governments and big businesses are keen to encourage cross-border economic activity on all levels, including small trade of consumables, but their Russian equivalents have other priorities. Focussed on border security as well as large-scale exports of oil, gas, military equipment and raw materials, Russian institutions have allowed the grassroots commercial development of Trans-Baikalia, Amur Oblast and Primorsky Kray to stagnate. The result is that these regions manufacture very little that the locals, let alone the Chinese, want to buy. Most residents depend on Chinese imports for the great majority of their clothing, shoes, domestic appliances, farm machinery, chemicals, utensils, furniture, toiletries, toys, mobile phones and even cheap fruits and vegetables. These form the great majority of the retail items sold in villages in the Siberian regions and provide income for large numbers of people who engage in the shuttle-trade. This consists of small teams of (mostly) women, working under a boss. The members of these teams hire themselves out to buy and carry goods from China for sale in Russia. The economic rationale is to lower the sale price by avoiding customs and license charges, under the pretence that each person has purchased the goods only for personal use. Laborious and risky, the border-crossing procedure involves not only paying bribes, but also unpacking the goods at customs to make them seem 'mine' and then re-packing them again in commercial wrappers to fit them for sale. Most of these 'traders' do not think of themselves as professionals they are simply people (students, single mothers, the unemployed, the underpaid, etc.) who urgently need both essential goods and money (Ryzhova 2008).

An aspect of the subjectivity involved in this work appears in the carriers' name for themselves: kemel (the English word 'camel', not the Russian word verblyud), which surely expresses a double alienation, representing oneself as an archetypal beast of burden and as 
a foreign-defined one at that. When citizens of Russia express their opinions, they often remark on the overall trade disparity as if it were fated, saying simply, 'They sell; we buy'. Thus, both the economic situation and the discursive images are imagined as disengaged and asymmetrical. The imbalance is reinforced by the fact that the vast majority of Russians cannot imagine a future for themselves as traders in China: they are hindered by legal restrictions, lack of language skills and contacts from setting up businesses on the Chinese side (Ryzhova 2008: 331).

It is in line with this dual asymmetry that a caricature has arisen in Russia of a cultural impasse, which is reflected both in popular media and academic articles. According to this, Russian consumers, with their Soviet production-oriented history, care above all about the quality, authenticity and purity of the goods they buy, rating these higher than price (Karpova 2007: 109); in contrast, the Chinese take delight in the very opposite - in copying, faking, adulterating and misleading (Yu 2012). Such quasi-mythic images are entangled with practical activity on the ground that often contradicts them. Most Russian shoppers enjoy the Chinese border town Manzhouli and are happy with their purchases. Nevertheless, their assessment of the situation as a whole and the Russia-China trade relation is negative (Peshkov 2018); melancholic hyper-suspiciousness is apparent, we could say. Russian netizens post, for instance, 'You take your life in your hands. It seems they make especially harmful things for Russians. Chinese goods are cheap, but poisonous', even when no actual case is cited. This wariness applies not only to foods, dried milk, etc., where it can be justified, but also to manufactured goods such as mobile phones and clothes. Qualic judgements are crucial. It is advised, for example, to smell children's toys before buying in order to detect the presence of harmful chemicals. ${ }^{3}$

What is interesting is the convoluted self-reflexivity involved. Some respondents blame the presence of toxicity on Russian consumers, i.e. broadly on themselves for choosing to buy 'dirt-cheap' goods that are not subject to safety checks. Others blame the unscrupulousness of Russian traders. One wrote, 'It all boils down to the fact that China is not 'China' to the Chinese. The quality of the things we get doesn't depend on them, but on the [Russian] client who makes the order and whether he intends to purvey false, substandard goods'. It is significant that this blogger does not describe the crooked client as some third person malefactor but as ' $\mathrm{I}$ ' in a series of hypothetical 
examples (e.g. 'Let us suppose I go to China and order copper cable but tell our Chinese friends to do it on the cheap and substitute another metal...etc.'). ${ }^{4}$ Such a subjectivity of the 'devious self' cannot be separated from the actuality of the moments of connivance, deception and suspicion in cross-border trade. Indeed, the Russian actors know that the business most fundamental to the local economy, the shuttle trade, is founded on schemes to defraud their own state. Yet, as long as the trade continues to provide work and profits, no one is planning to change.

'What else can I do?' said one woman, a shuttler for eight years already. She was 28 years old, with no other income and a young child to care for. 'I can't take orders and go and work for someone. For some wretched 5,000 roubles? Come off it! I have no money to start an independent business. I can't even think of that. No, I'll stick it out to the end, come what may'. ${ }^{5}$

\section{Border Temporality}

The regulatory and economic circumstances of borders change, and with them the spatial practices, memories and narratives (Hurd, Donnan and Leutloff-Grandits 2017:1). After Russian citizens were enabled to travel more easily to China on short-stay group visas, people became acutely aware of currency swings and price differences across the border. The free-for-all bonanza of the 1990s was soon over, but Manzhouli was still said to have been 'heaven' for shopping-tourists ${ }^{6}$ in the 2000-2010s. The post-Soviet unease with trading, rooted in the previous ideological disapproval of 'speculation', evaporated. A study in the border town Blagoveshchensk showed that traders gradually accepted the idea that ruthless capitalism is Russia's new reality in which they themselves must participate (Ryzhova 2020). Visits became much more expensive after the fall of the rouble in 2014-2016. Yet bargains were still to be had, and the light-hearted, fun ambiance of cities like Manzhouli and Heihe continue to attract people. Still, the Russian disadvantage has deepened. Shuttle-traders now work for Chinese rather than Russian bosses. In Manzhouli, street markets have largely been replaced by boutiques and malls, which are considerably larger, brighter and more impressive than the ones in Siberia. They include services such as classy restaurants, coffee shops, tailors, escalators, nail bars, saunas, changing rooms with mirrors, signage in Russian and clean toilets. 
In this environment, as shown in a study by Dieter Stern (2015), the Chinese retailers have been trying to recalibrate their relations with Russian customers. In 2013, Manzhouli was designated a 'civilised port of national importance'. This declaration was associated with a policy for developing the northern border regions, including enhancing the tourist industry to make the city appeal to not only international but also Chinese tourists. Faced with the falling buying power of the rouble and fewer Russian visitors, Manzhouli survives by playing on its phantasmagorical 'Russian character' to entice tourists from central China eager to see a glimpse of 'Europe'. 'Civilisation' (wenming) is the key to these changes, for the tourists now sought after are from the relatively prosperous Chinese middle class, the embodiment of polite wenming values. The previous unregulated social relations between numerous tiny firms have been tightened into hierarchies that link businesses vertically (Ryzhova 2020). The Chinese retailers still order goods from southern manufacturers, reflecting their view of Russian customers' preferences, but otherwise they are subject to top-down urban spatial planning and municipal regulations. The shopkeepers have to pay high rent and taxes, and this means they can no longer run a 'bargain basement' type of operation. They have to raise both the quality of the goods and the prices.

Much of this wenming excellence arouses delighted praise from the Russian shopping-tourists. ${ }^{7}$ However, many Russian customers, especially the older generation, have not abandoned the civilisational model of Russian (European) cultural superiority. Advised by online travel sites of the need to bargain, they scoff at the price named by the seller, name some absurdly low figure and insist on haggling. At home, in Russian-managed shops, purchasers usually do not bargain, and so attempting to beat down the price seems to be a practice adopted specifically when dealing with traders categorised as 'oriental'. A peremptory tone is often employed, using imperatives and the familiar (impolite) form of 'you' ( $t y$ instead of $v y$ ), and speaking in the kind of broken Russian imagined to be understandable by Chinese salespeople (Fedorova 2012). Accustomed to non-commercial Russian public manners, the Russian visitors are irritated by 'importunate' traders and they express indignation that faulty goods are not exchangeable. What is interesting is that imaginaries of international politics are part of this scene. Local travel/shopping Internet sites bolster Russian courage with narratives of the Red Army liberating 
Manchuria from the Japanese fascists in 1945 and pictures of valiant Trans-Baikal Cossacks who conquered the borderlands. ${ }^{8}$ Meanwhile, the Chinese shopkeepers also have a newfound patriotism and global stance, demonstrated by notices outside their boutiques: 'No entry to Japanese' (this is not much of a loss, since very few Japanese find their way to Manzhouli). According to Stern (2015), despite the possible rapprochement hailed by recalling wartime alliance and socialist solidarity, in the streets, misunderstandings between Chinese and Russians are common; angry scenes can occur and a significant number of transactions are broken off.

Be that as it may (I myself did not witness such scenes), the main energy and inventiveness of Russian traders is not in reality directed against their Chinese counterparts. From them, they only need to get a fair deal. The dangerous hidden enemies are on the Russian side not only the customs officers, but the entire apparatus of predators in the security services, municipalities, licensing bureaux, etc. who attempt to extort a share of profits. The uneasy question, 'What has happened to Russia that it should be this way?' lay behind the anguished cry of a trader: 'It's not my fault!', when her Chinese boss flew into an uncontrollable rage as she told him of yet another change of regulations (also, opportunity for extraction) by the Russian authorities (Ryzhova 2020: 163).

\section{Trade Goods and Branding at the Border}

To understand the link between 'social qualia' and trade goods, it is necessary to look at the practice of branding. In Russia, whole industries are devoted to the concoction of logos, packaging design and the commercialisation of Soviet and Putin-era cultural iconography (Roberts 2016; Daucé, et. al. 2015: 4). Lash and Lury (2007: 6) argued in their seminal work on the 'mediation of things' that goods as commodities are all alike - iron is iron, potatoes are like other potatoes - while brands have value, above all because they promote difference: their distinctiveness from other brands. However, the contrast between 'commodity' and 'brand' breaks down in border situations where there are strong negative stereotypes of the 'other', and the brand merges with the perceived or advertised country of origin. The idea of the brand is broader than that of the trademark (a registered label or logo), and if we take it down to the very basics, it is evident that even commodities such as vegetables can become brand- 
ed goods of a sort. For example, Russian shoppers in Blagoveshchensk have a prejudice against 'Chinese cucumbers', recognised by the little stem left on the vegetable. Convinced it is produced in ecologically purer conditions, ${ }^{6}$ they prefer to buy the 'Russian cucumber', which is physically identical except that the stem is cut off. ${ }^{9}$ Of course, it did not take long for the sellers of Chinese cucumbers to remove the stems and market their cucumbers as 'Russian'. This example illustrates one aspect of brands - they stand for ideas that are applied to objects, which then come to exist as brands, whatever their actual content or origins. In this case, the 'brand-sign' of the stem indexed something invisible: the supposed process of production of the cucumbers ('with chemicals' as opposed to ecologically) that was otherwise not evident. Yet it is probable that knowledge of which 'brand' one was consuming would alter the qualic experience of eating.

The broader context in which branding takes place at the border has both a history and a geography. Already in the late 1990s to early 2000s, Melissa Caldwell (2002) noted the influence of patriotism on the consumption of foods in Moscow. Foods were classified as 'Ours' (nash) and 'Not Ours' (ne nash), and the local products were advertised as superior to foreign ones in terms of taste, quality and healthfulness (Caldwell 2002: 296-7). This early post-socialist branding was recognised by the public to link to wider economic and political identities. As Caldwell observes (2002: 313):

By linking their individual food experiences with broader political and economic concerns, Muscovites articulate practical ideologies of national loyalty that affirm membership and participation in a more singular, homogenous Russian experience. In the face of growing income disparities and class stratification, each conscientious consumer of ' $n a s h$ ' foods remains a committed member of the 'nash' collectivity of Russians.

Since then, in both Russia and China (Zhao 2013), there has been a surge in the creation of national brands that can be seen to emerge from the respective histories and values of each country. However, this does not mean that brands carefully designed for their respective citizens necessarily travel well in the global environment, or across their mutual border. Varieties have to be invented specifically for export. Chinese traders in Russia do not market the restrained simplicity of high-end Chinese fashion but supply clothing that will appeal to the particular tastes of their Russian customers. The result is that 
on both sides of the border, Russian consumers in the trade centres and shopping streets can choose amongst a range of several kinds of goods:

- Cheap clothing, footwear, cosmetics, etc., not labelled or branded

- Goods provided with a meaningless logo, which looks as though it might be a brand

- Better quality goods, labelled with Russian, Vietnamese, Turkish or Chinese brands, such as PLIST, Li Gao Jeanz, BT boy and HaiLooZi

- Pricey copies of international branded goods, but made in South China

- Most expensive of all: genuine brand products made in Europe, USA, Japan and increasingly China

At present, commerce in the border towns is still dominated by the cheaper, un-labelled products aimed at supplying low-income groups. These goods have a very different aura than the old Soviet products. The latter were mostly without brands because they were defined as basic needs produced by the people for the people: standardised bread, cheese, cloth, felt boots, etc. The contemporary brand-less goods are a kaleidoscope of fancies washing in from unknown lands in every shape and size, all different and yet all chaotically mixed together in each shop, and therefore all seeming, somehow, to be the same. Many consumers preferred not to admit buying such things and appearing to be 'poor' (Zhuravskaya 2012: 15). If possible, they aimed to move up the scale and buy locally appreciated brands or products labelled with a global brand name, not caring too much about whether the item was counterfeit or not. As one Russian journalist wrote:

We long ago stopped buying simple things - simply a shirt, or simply jeans. We buy brands and the style put into these things. Isn't that so? It is! [...] Fashion and brands rule contemporary shopping. You might not like this. But that's the way it is! (Pometkin 2010)

With the fundamental shift brought about by branding, economic values have come to rest increasingly on the labile symbolic aspects of goods (Manning and Uplisashvili 2007: 629; Ermann 201: 174). I would suggest that this shift now needs to be understood in relation to the highly equivocal mediatisation of 'real life'. In an important article, Alexei Yurchak (2018: 96) argues that in Russia (and not Russia alone), when federal TV channels with audiences of a hundred million mix real facts with fake facts: 
Caroline Humphrey

The main effect of this practice is not necessarily that the audiences are fooled into believing every imaginary story and fact, but rather that they learn that "facts" may be read not for how true or false they are, but for how effective or ineffective [...] they are.

In other words, such an audience apprehends the story for how successfully it represents, rather than for how truthfully it represents. I suggest that consumers' concern with the effect of brand symbolism is a practice that is part of this same world of chimerical representation. 'Effects' then bring me back to the idea of qualia.

\section{Qualia in a World of Irony}

There is a literature on brands that focuses on semiotics, the meaningcontent signified by the brand or trademark as a sign (Manning and Uplisashvili 2007: 629). Other authors, however, emphasise less the informational meaning and more the broader aura of feelings, physical sensations, emotions and moral landscapes. Interestingly, this approach derives in part from branding practitioners. According to Marc Gobé, who designed the emotion-driven brand strategies for Coca-Cola, IBM, Versace and Starbucks, it is crucial that the brand 'focuses on the most compelling aspects of the human character, the desire to transcend material satisfaction and experience emotional fulfilment. A brand is uniquely situated to achieve this because it can tap into the aspirational drives, which underlie human motivation' (Gobé 2001: xv). Nike taps into the appetite for youth, energy and physical health; Dolce \& Gabbana feeds on aspirations for social - chic, European - exclusivity, and so forth.

As Lemon (2013: 68) observes, the qualia by which people in Moscow perceive (feel or imagine) a material affordance or a quality, at the same time express a relationship. She gives the example of a Marlboro cigarette: it provides a certain taste sensation, and at the same time, via countless media images, puts the person smoking it in a relationship with 'cowboy America' - a relation that can be felt both as intimate and a vast gap of space and time. In the border situation, the same applies even to the cheap unlabelled goods in bazaars, because they are already quasi-branded in consumers' minds as 'made in China', evoking images perhaps of sweatshops in dusty cities. With more ambitious marketing, the more the consumer is made aware of branding practices through media manipulation (the 'story', emotional pull or the affect conveyed 
by colours, textures, typefaces or accompanying music in advertisements, etc.), the more ambivalent becomes the space between herself and the projected positive image. The effectiveness is still there, but it is combined with awareness of distance, and hence opportunities for subversion or mockery. In other words, in the present media-saturated world, alienation and self-reflexivity are all part of the art of consumption, i.e. they are aspects to be acted upon in the relationship with imagined worlds conjured by brands.

Let me now try to ground these general points with an example from the social realities of Sino-Russian trade. Dolce \& Gabbana's (D\&G) glittery bead-encrusted frocks, shoes and handbags represent the essence of La Dolce Vita extravagance. The brand is highly popular in Russia, with several stores and boutiques in the larger cities. From the D\&G designers' point of view, the Italian and Russian senses of style and beauty merge into one, so there is no need for them to create special designs for Russians. On a visit to Moscow to open their largest store, surrounded by celebrities, Domenico Dolce said:

[Russia] has been a wonderful market for Dolce and Gabbana for a long time, and we are lucky that women in Russia have such beautiful bodies. It's incredible. [...] We feel that Italians and Russians are very similar deep inside. [...] Think of our last collection, which features mosaics on the dresses. They could have been taken from a Russian cathedral, but they came from Palermo, and you couldn't tell the difference. ${ }^{10}$

Such statements make it clear that Russian women are meant to share the same aura of beauty and elegance as consumers of D\&G worldwide. But what do we find in the Siberian border cities? Here, there are no licensed D\&G boutiques, and 'authentic' D\&G outfits are rare in the extreme. But the brand is consumed, nevertheless, in street markets in the form of lurid pink, yellow and blue male underpants.

In the marketplace, there is no energetic pretence that the pants are the real item. What is happening here is basically playful, emphasised by the qualic fluorescent colours. It is conceivable that some Siberian consumers have not heard of $D \& G$, can hardly read the writing and know the pants are probably made in China, and yet when wearing them, they still feel they have become more stylish and European. That logo, so foreign and cool with its big letters across the waistband, conjures images of male models in sunlit scenes, a 
different world from the shabby markets of home. This experience is not incompatible, at least among some of the younger generation, with mocking it at the same time. Buying such pants could be something of a joke, or even a personal protest, which could be upbeat and melancholic, against both the real D\&G elegance they do not have the means to access and against the patriotic injunctions to have nothing to do with 'Western trash'.

\section{Melancholic Subjectivities and Global/Historical Imagination}

I end with two ethnographic illustrations in order to show how Russians' apprehensions of the globalised capitalism of China reveal a subjectivity that is at once 'melancholic' (in the sense outlined earlier), sceptical and global in scope. In October 2014, a video advertisement for Huawei's new smartphone, Honor 3, was posted on Russian YouTube. ${ }^{11}$ In a few days, it was seen by over a million viewers. The film depicts a band of Russian criminal types torturing a businessman to get him to pay off a debt. They have tied him up, and amid threats, he is lowered into a vat of water. He screams for mercy, but as they lift him out of the water, the phone in his pocket rings. The bandits take an interest: 'So your phone is waterproof, is it?' 'It is', he gasps. 'How many megapixels?' 'Thirteen', he replies. Forgetting the debt, the gang boss grabs the phone, and the film ends with the gang boss using it to ring to his girlfriend and tell her in melting tones that he has found just the new phone for her.

What is interesting about this brand promotion is that plays on national stereotypes present in both China and Russia. Yet its effect was unintended, as can be seen from the websites revealing the hurt and anger it generated in Russia. Clearly having brooded on such matters, people uploaded other examples of foreigners trying to sell their brands by making use of negative stereotypes about Russia. One commented that Huawei's video is saying that in Russia everything is decided by brute force; just as Nissan's marketing for its Almera ('a tough car suitable for Russian roads') rests on the 'common knowledge' that Russian roads are terrible; the Audi Quattro, depicted in endless snowstorms, harks to the assumption that it is always cold in Russia, and so forth. Evidently, the qualia conveyed by Huawei's Honor 3 video - dark colours, growling voices, the terror of the businessman, the threatening soundscape - evoked an im- 
age that was rejected by Russian consumers as referring to themselves. The online comment firmly relegates the scene to a historical time, the 'bandit era' of the 1990s. Pervading all this is the melancholia of loss of prestige in the comparison of nations. This was expressed in very various ways. Some contributors were downright angry ('Idiots! We'll wipe out your phones and crush them with a bulldozer'), though others decided that the video must be ironic and wrote that viewers should learn to appreciate humour. Yet another mockingly congratulated the Chinese media for overcoming the problem that the name Huawei sounds like a Russian swear word. ${ }^{12}$

The physical actuality of border trade provides my second case, showing that this too is associated with melancholic subjectivity. A Russian citizen of Buryat ethnicity who recently (2019) took up shuttle work out of economic necessity posted on social media a photograph of herself next to a street statue in Manzhouli depicting cross-border traders.

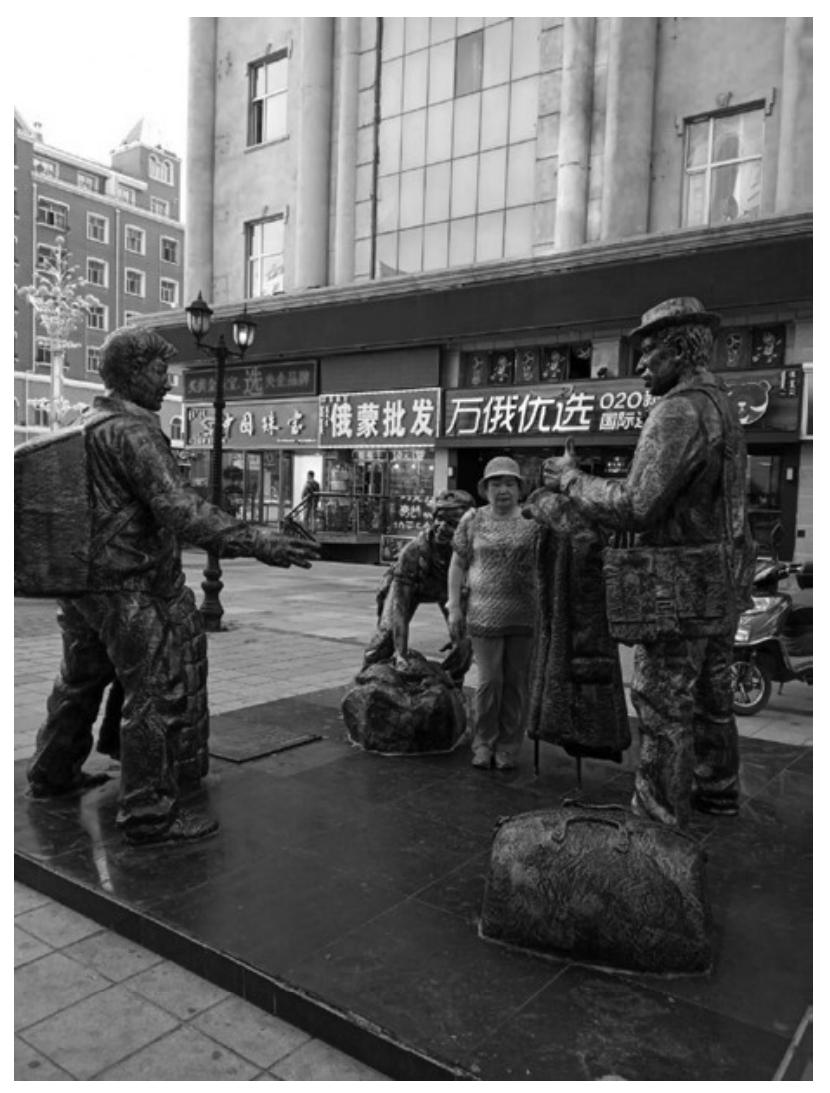

Illustration 1. A

Russian shuttle trader poses by a Chinese monument to shuttle traders, Manzhouli 2019.

Source: Photo by Tsindyma Dashbalova. 
Even though the statue represents men traders, she evidently took it to refer to people like herself, commenting:

Probably this is a monument to all of our Russian women - heroines, who carried from China on their broad shoulders not only fur coats but also every kind of clothing and footwear, all in order to feed their families, children and grandchildren. It is they who saved our country all these years and they are still saving it!

To which her friend gave a downbeat response:

Yes, in the 1990s Nina also fed her family that way. They were young and strong then. They didn't spare themselves or their health. But it showed up in later life. Women traders, take care of your health! ${ }^{13}$

For these women, the statue in China triggered memories of qualic experiences: of staggering under heavy baggage, of stony unpaved roads, of years of adapting to changing regulations, abusive police and customs, flint-hearted bosses - and somewhere behind this is the melancholic imagination of an earlier time, of a lost world that was different, a country that did not have to be saved in this way.

\section{Conclusion}

This article has argued that the asymmetries between the Chinese and Russian economies have generated particular subjectivities among Russian participants in cross-border trade. This is associated with the fact that the economic activities of the actors from each side tend to be different, the Chinese being predominantly producers and sellers, the Russians consumers and buyers. It has been suggested that qualia - the sensed experience and the affect generated by the trade goods themselves - are peculiarly important for people who combine trading with consuming. For these people, the experiential quality of goods that have to be worn or ingested (by themselves, their families and countrymen) is a matter of concern, even moral concern. Felt experience includes the imaginative associations of the goods. These may involve anxieties about how the items, such as foodstuffs, have been produced, which is encoded in spontaneous word-of-mouth branding. In the case of clothing, cosmetics and electronics, the glowing brand images of what these goods are meant to stand for may be eagerly accepted, but may also arouse a sense of distance, alienation and hurt pride. The fact that the border economy involves purveying these, always at some level alien, Chinese goods, and making a profit from them, and while also deceiving the Russian authorities is one ground 
for the formation of what I have termed 'melancholic' subjectivities. Following Navaro-Yashin (2009), I have argued that another deeper layer, a melancholic sense of loss, also underlies the uneasy, dangerous and laborious practice of shuttle-trading, at least for the older practitioners. It is hard to sustain an assumption - even a memory - of Russian/Soviet civilisational superiority when being caught between the ramparts of Chinese economic success on the one hand, and the venal reality of Siberian borderland poverty on the other. Melancholia in these circumstances may take the form of regret, but it also morphs into many less obvious expressions: defiance, cynicism, mockery, self-reproach, defensive cunning and determined stoical endurance.

\section{ACKNOWLEDGEMENTS}

The research on which this paper was based was supported by a UK ESRC grant ES/J012335/1 'Where Rising Powers Meet: Russia and China at their North Asian Border'.

CAROLINE HUMPHREY is Emeritus Sigrid Rausing Professor of Anthropology at the University of Cambridge and a Research Director of the MongoliaandInnerAsiaStudiesUnitintheDepartmentofSocialAnthropology. Recent publications include: Trust and Mistrust in the Economies of the China-Russia Borderlands, Amsterdam University Press, 2018. Email: ch10001@cam.ac.uk

\section{NOTES}

1 Tobias Holzlehner, who carried out fieldwork in Vladivostok in the 2000s, wrote in his PhD thesis that for Russian purchasers the foreigners selling on the market are known by the goods they are linked with; goods which act in this city as catalysts for xenophobia. Quoted in Ryzhova (2020: 165).

2 Freud distinguished between 'melancholia' and 'mourning', a conscious process of adaption to a known loss. 'Melancholia contains something more than normal mourning. In melancholia, the relation to the object is not a simple one; it is complicated by the conflict due to ambivalence' (Freud 1957: 256).

3 http://anna-news.info/node/4486, dated 2014, accessed July 2019.

4 http://www.100voprosov.net/forum/sto-voprosov-sto-otvetov/bezopasnost / kitaiskie-tovary-kak-vybirat.html, accessed October 2018.

5 From an interview conducted in Blagoveshchensk (Ryzhova 2020: 142).

6 The 'shopping tour' is a major way for Russians from towns like Irkutsk, UlanUde, Zabaikal'sk and Chita to visit Manzhouli. Passports and payment are 
Caroline Humphrey

handed over in advance to the tour operator, who organises the group visa, hires a bus and driver, books the hotel and arranges visits to shopping centres and restaurants. Such tour groups may include people who are shuttle-traders working for professional trade firms.

7 For descriptions of Russian shoppers' experiences in Manzhouli in 20162018, see https://irecommend.ru/content/samaya-dostupnaya-zagranitsa, http://otzyv.expert/gorod-dlya-pokupok-554720 and http://tuda-suda .net/2016/06/manchzhuriya-china/.

8 See the 'Manchzhuriya' website for Russian shoppers, https://vk.com/topic -6438067_28445677, accessed August 2019.

9 These Russian cucumbers are known as 'Teplichnye' (grown in a greenhouse), a name which functions like a brand (Nataliya Ryzhova, personal communication).

10 http://rbth.co.uk/arts/2014/03/25/dolce_and_gabbana_beauty_is_in_the_ russian_dna_35339.html, accessed October 2014.

11 'Telefon dlya Rossii.' http://www.youtube.com/watch?v=M_cVHdedwik, accessed 28 January 2018.

12 See comments at http://www.youtube.com/watch?v=M_cVHdedwik, accessed 29 January 2018.

13 I thank Sayana Namsaraeva for providing me with this example and Tsindyma Dashbalova for allowing me to use her photograph.

\section{REFERENCES}

Bassin, Mark, Sergey Glebov and Marlene Laruelle (eds.) 2015. Between Europe and Asia: The Origins, Theories and Legacies of Russian Eurasianism. Pittsburgh: University of Pittsburgh Press. https:/ / doi. org/10.5823/jarees.2015.120.

Billé, Franck 2017. 'Skinworlds: Borders, Haptics, Topologies'. Environment and Planning D: Society and Space 36 (1): 60-77. https:/ / doi. org/10.1177/0263775817735106.

Caldwell, Melissa 2002. 'The Taste of Nationalism: Food Politics in Postsocialist Moscow'. Ethnos 67 (3): 295-319. https:/ / doi.org/10.10 80/0014184022000031185.

Cassidy, Kathryn 2017. 'Border Crossings, Shame and (Re-)Narrating the Past in the Ukrainian - Romanian borderlands'. In Donnan, Hurd and Leitloff-Grandits (eds.) Migrating Borders and Moving Times: Temporality and the Crossing of Borders in Europe. Manchester: Manchester University Press, pp. 58-79. https://doi.org/10.7765/9 781526116413.00010.

Cherkaev, Xenia 2014. 'On Warped Mourning and Other Omissions in Post-Soviet Historiography'. Ab Imperio 4: 365-385. https:/ / doi. org/10.1353/imp.2014.0121.

Chumley, Lily Hope and Nicholas Harkness 2013. 'Introduction: Qualia'. Anthropological Theory 13 (1-2): 3-11. 
Clewell, Tammy 2004. 'Mourning Beyond Melancholia: Freud's Psychoanalysis of Loss'. Journal of American Psychoanalytic Association 52 (1): 43-67. https:// doi.org/10.1177/00030651040520010601.

Daucé, Francoise, Marlene Laruelle, Anne Le Huérou and Kathy Rousselet 2015. 'Introduction: What Does it Mean to be a Russian Patriot?' Europe-Asia Studies 67 (1): 1-7. https://doi.org/10.1080/096681 36.2014.986964.

Donnan, Hastings, Madeleine Hurd, Carolin Leutloff-Grandits (eds.) 2017. Migrating Borders and Moving Times: Temporality and the Crossing of Borders in Europe. Manchester: Manchester University Press. https://doi.org/10.26530/oapen_626398.

Ermann, Ulrich 2013 'Fashioning Markets: Brand Geographies in Bulgaria'. In Duijzings (ed.) Global Villages: Rural and Urban Transformations in Contemporary Bulgaria. London: Anthem Press, pp. 173-190.

Fedorova, Kapitolina 2012. 'Transborder Trade on the Russian-Chinese Border: Problems of Interethnic Communication'. In Bruns and Migglebrink (eds.) Subverting Borders. Wiesbaden: Verlag fur Sozialwissenschaften, pp. 107-128. https://doi.org/10.1007/978-3531-93273-6_6.

Freud, Sigmund 1957 [1917]. Mourning and Melancholia. The Complete Psychological Works of Sigmund Freud. Vol. 14. London: The Hogarth Press.

Gobé, Marc 2001. Emotional Branding. New York: Allworth Press.

Goode, J. Paul 2018 'Everyday Patriotism and Ethnicity in Today's Russia.' In Kolsto and Blakkisrud (eds.) Russia Before and After Crimea: Nationalism and Identity, 2010-2017. Edinburgh: Edinburgh University Press, pp. 258-281. https://doi.org/10.3366/edinburgh/9781474433853.003.0012.

Humphrey, Caroline 2012. 'Concepts of "Russia" and the Relation to the Border with China.' In Billé, Delaplace and Humphrey (eds.) Frontier Encounters: Knowledge and Practice at the Russian, Chinese and Mongolian Border. Cambridge: Open Book Publishers, pp. 55-70. https://doi.org/10.11647/obp.0026.04.

Karpova, Elena 2007. 'Making Sense of the Market: An Exploration of Apparel Consumption Practices of the Russian Consumer'. Journal of Fashion Marketing and Management 11 (1): 106-21. https:/ doi. org/10.1108/13612020710734436.

Lacaze, Gaelle 2012. 'Prostitution and the Transformations of the Chinese Trading Town of Ereen'. In Billé, Delaplace and Humphrey (eds.) Frontier Encounters: Knowledge and Practice at the Russian, 
Caroline Humphrey

Chinese and Mongolian Border. Cambridge, Open Book Publishers, pp. 111-135. https:/ / doi.org/10.11647/obp.0026.07.

Lash, Scott and Celia Lury 2007. Global Culture Industry: The Mediation of Things. Malden: Polity. https://doi.org/10.1017/ s0008423908080931.

Lemon, Alaina 2013. 'Touching the Gap: Social Qualia and Cold War Contact'. Anthropological Theory 13 (1-2): 67-88. https://doi. org/10.1177/1463499613483400.

Li, Ling 2012. 'Technology Designed to Combat Fakes in the Global Supply Chain'. Business Horizons 56 (2): 167-77. https://doi. org/10.1016/j.bushor.2012.11.010.

Lin, Yi-Chieh Jessica 2011. Fake Stuff: Chinaand the RiseofCounterfeit Goods. London: Routledge. https://doi.org/10.1177/1469540512456941.

Luhrmann, T. M. 2006. 'Subjectivity'. Anthopological Theory 6 (3): 345-361.

Manning, Paul and Ann Uplisashvili 2007. "“Our beer”: Ethnographic Brands in Postsocialist Georgia'. American Anthropologist 109 (4): 626-41. https://doi.org/10.1525/aa.2007.109.4.626.

Navaro-Yashin, Yael 2009. 'Affective Spaces, Melancholic Objects: Ruination and the Production of Anthropological Knowledge'. Journal of the Royal Anthropological Institute (N.S.) 15: 1-18. https:/ / doi. org/10.1111/j.1467-9655.2008.01527.x.

Peshkov, Ivan 2018. 'The Trade Town of Manzhouli: Trust Created and Undermined.' In Humphrey (ed.) Trust and Mistrust in the Economies of the China-Russia Borderlands. Amsterdam: Amsterdam University Press, pp. 121-142. https:// doi.org/10.2307/j.ctt22zmbb1.9.

Pometkin, Grigorii 2010. 'Samyi bol'shoi v mire rynok poddelok'. http://greenbag.ru/china/kitaiskii-rynok-poddelok. Accessed January 29, 2018.

Reeves, Madeleine 2013. 'Clean Fake: Authenticating Documents and Persons in Migrant Moscow'. American Ethnologist 40 (3): 508-524. https:/ / doi.org/10.1111/amet.12036.

Roberts, Graham H. J. 2016. Consumer Culture, Branding and Identity in the New Russia. London: Routledge.

Ryzhova, Natalia 2008. 'Informal Economy of Translocations: The Case of the Twin City of Blagoveshchensk - Heihe'. Inner Asia 10: 323-51. https:/ / doi.org/10.1163/000000008793066731.

Ryzhova, Natalia 2020. Integratsiya ekonomicheskikh migrantov v regionakh Rossii: formal'nyye i neformal'nyye praktiki. Irkutsk: Ottisk.

Stern, Dieter 2015. “"Nado minimum!": Mediating Respectability at Informal Markets on the Russian-Chinese Border'. Inner Asia 17 (1): 5-30. 
Yu, Hua 2012. China in Ten Words. Translated by Allan H. Barr. New York: Anchor Books.

Yurchak, Aleksei 2018. 'Fake, Unreal, Absurd'. In Copeman and Da Col (eds.) Fake: Anthropological Keywords. Chicago: HAU Books, pp. 91-108.

Yuval-Davis, Nira, Georgie Wemyss and Kathryn Cassidy 2017. 'Introduction to the Special Issue: Racialized Bordering Discourses in European Roma'. Ethnic and Racial Studies 40 (7): 1047-1057. DOI: 10.1080/01419870.2017.1267382.

Zhao, Jianhua 2013. The Chinese Fashion Industry: An Ethnographic Approach. London: Bloomsbury. 